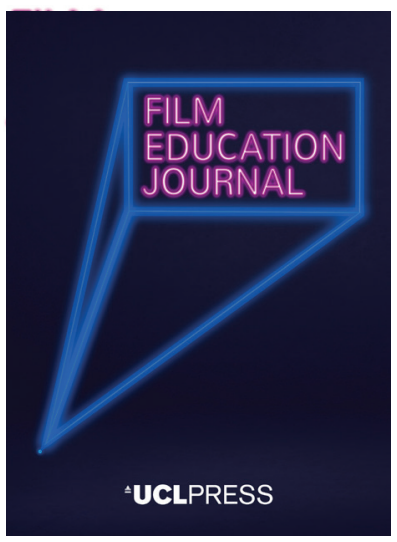

UCLPRESS

FILM EDUCATION JOURNAL

ISSN 2515-7086 (Online)

Journal homepage:

https://www.uclpress.co.uk/pages/film-education-journal

\title{
Greek teenagers' cultural taste and identity expression through a documentary-making project
}

\section{Eirini Arnaouti iD}

\section{How to cite this article}

Arnaouti, E. (2021) 'Greek teenagers' cultural taste and identity expression through a documentary-making project'. Film Education Journal, 4 (1), 44-57. https://doi. org/10.14324/FEJ.04.1.04

Submission date: 6 April 2020

Acceptance date: 13 November 2020

Publication date: 10 June 2021

\section{Peer review}

This article has been peer-reviewed through the journal's standard double-blind peer review, where both the reviewers and authors are anonymized during review.

\section{Copyright}

(C) 2021 Arnaouti. This is an open-access article distributed under the terms of the Creative Commons Attribution Licence (CC BY) 4.0 https://creativecommons.org/licenses/by/4.0/, which permits unrestricted use, distribution and reproduction in any medium, provided the original author and source are credited.

\section{Open access}

The Film Education Journal is a peer-reviewed open-access journal. 


\title{
Greek teenagers' cultural taste and identity expression through a documentary-making project
}

\author{
Eirini Arnaouti* - UCL Institute of Education, UK
}

\begin{abstract}
This article explores a film education project conducted on an extra-curricular afterschool basis in a Greek secondary school in Tampouria, Piraeus. A documentarymaking project exploring the area around the school was realized by a group of ten 15-year-old students under the supervision of their English teacher/researcher. The following case study explores how aspects of the students' cultural taste and identity were expressed through this moving image literacy project, carried out in a foreign language. Various forms of data - observation, textual and audiovisual are analysed within a social semiotic framework. The article seeks to demonstrate how the students' cultural taste was formed by different kinds of global and local influences, and how aspects of their multifaceted identities were revealed during the documentary-making process, and expressed through the creation of media texts within a context of Greek education.
\end{abstract}

Keywords: cultural taste, glocal, identity, documentary film, Greece

\section{Introduction}

This article explores a small-scale case study I conducted while working as an English teacher/researcher in a secondary school in the area of Tampouria, in Piraeus, Greece. Tampouria is an area with a rich historical heritage, beginning in Greek antiquity, and highlighted by its contribution to the Greek Revolution against the Ottoman Turks in the nineteenth century, and the reception of Asia Minor Greek refugees in the early twentieth century. At the time of writing, Tampouria is now an industrial neighbourhood of Piraeus with a high percentage of economic immigrants, mainly from the Balkans and Eastern Europe. It has some factories and a commercial port, where most of its inhabitants work. The school itself might thus be characterized as working class due to the socio-economic status of both the surrounding area and the students' parents, most of whom were secondary or high-school graduates and performed manual jobs, while a high percentage of them were unemployed.

The extra-curricular cultural project I organized on an after-school basis was joined (on a voluntary basis) by ten students (nine girls and one boy) during a sevenmonth period, for three hours per week. Five of the students were Greek, four were second-generation Albanian (including the boy) and one was Greek-Slovakian. The students were of mixed competencies, ranging from those with a high level of experience to those with less, participating in the project because of their interest in videos and their love for their neighbourhood. Regarding videos, Student H wrote, 'I have tried to make digital videos. ... I have shot some videos with my friends on my 
mobile phone and I have edited them on a program there.' Additionally, Student P mentioned that 'I enjoyed this documentary project because I dealt with the history of ... the place where I grew up.'

\section{Method and research context}

I chose to introduce students first to theoretical understandings of media work. In education systems where media education is part of the national curriculum, teachers are typically provided with suggested material and predetermined bibliographies to use in their projects (Dyson, 2002); this is not the case in Greece. In the absence of any such guiding approach, I pieced together a theoretical approach and bibliography drawn from a variety of international sources. I created a series of PowerPoint presentations on the main principles of film-making according to Bordwell and Thompson (2010), and the main principles of documentary-making according to Benyahia (2007) and Nichols (2010). These aspects of theory were illustrated with examples from popular films and wildlife documentaries with which students were familiar. To consolidate the students' acquired knowledge, we conducted an analysis of a documentary on the Greek island of Samos from the Greek Radiotelevision (ERT) archive, and the director of the documentary subsequently visited the school to talk with the students. Following these activities, I asked students to apply the documentary-making techniques they had learnt in structuring their prospective media texts, without interfering in their choices so as not to affect the results of the subsequent case study. My input in this respect was limited to guiding the students through answering questions and providing clarification, and to helping them with time management. Students were first divided into groups according to their interests and talents, with responsibility for different parts of the film-making process. For example, one group was tasked with writing the script for the film, the final version of which was discussed by the class as a whole. At the end of each stage of the process, the completed task was presented to the class as a whole, and modifications were made in accordance with the feedback received both from their peers and from me.

The process of making the documentary started with the collection of archive material and historical information, as well as with the search for witnesses to be interviewed. After the students had prepared a script in terms of narration and interviews, they decided first on the images and then on the soundtrack that would accompany the spoken word. Finally, they focused on finalizing the edit through the use of transition effects, as well as on the beginning and end titles and English subtitles. The final short documentary consisted of stills of places and paintings, video shots of the local area, of two students breakdancing and of two interviewees, transition effects, voice-over, soundtrack, beginning and end titles, and English subtitles. It was divided into two thematic sections: Tampouria of the past, referring to the history of the area from ancient times to the late twentieth century; and Tampouria of the present, referring to the period from the late twentieth century until now. The completed documentary was screened at the end-of-school-year celebration.

The final film, Tampouria of Yesterday and Today (which can be viewed at https://youtu.be/XtVuRtD6BTM), dealt with the history of the area around the school. Documentary was chosen as a genre because schools are allowed to realize extracurricular projects provided they are related to the curriculum, according to the regulations of the Ministry of Education, Lifelong Learning and Religious Affairs (2010). Documentary is relatively widely recognized as an educational film genre in Greece. The project was realized in English as a foreign language, which is not usually the case 
with moving image projects (Gilje, 2010; Parola and Ranieri, 2010; Pérez-Rodríguez and Delgado-Ponce, 2012), and it sought an interdisciplinary approach, combining media education with the subjects of history and foreign language.

In what follows, I seek to explore the experiences of the group of teenage students who engaged in this moving image project for the first time, and how the students can subsequently be seen to have expressed their cultural tastes and multifaceted identities within the Greek education system. I examine the role that national, generational and social characteristics played in students' cultural preferences, and within a documentary-making project, and how these choices might be seen to reflect aspects of their identities. As these aspects of cultural taste and identity were often complexly intertwined, they are analysed together.

The project's research context can be seen as multidimensional for a number of reasons: first, while Tampouria has a rich historical and cultural heritage, it has subsequently experienced aspects of significant poverty, and it is now considered to be a relatively disadvantaged inner-city neighbourhood. In this respect, the neighbourhood's historical value was an aspect that the students wanted to highlight. Second, while the students were tasked with depicting the neighbourhood on the basis of the 'official' understandings of history they had been taught, they chose at times to diverge from this in the service of their own representational tastes and needs. Finally, the project highlighted the manner in which historical themes can be subjective when seen through the lens of different nationalities, given that the student group consisted of mixed nationalities.

I sought to answer two research questions. First, what did the students' work reveal regarding their own and their community's cultural taste in terms of nationality, generation and social class? Second, what aspects of their identities came to light during this project?

My own role within the project can perhaps best be described as a 'participant observer' (Bailey, 1994: 243), in that the project allowed me to study the behaviour of its participants relatively continuously while making notes about their distinctive characteristics (Bailey, 1994: 243-4). The time spent and the relationships developed by participant observers with those they are observing frequently leads to what Cohen et al. (2007: 259) describe as a more 'natural' research context, given that phenomena are studied in real time and place, and experienced from inside. As a teacher, I also led English classes with the student-participants, and my knowledge of their personalities in this respect proved useful, both when recording observations and during the analysis of my data. Cohen et al. (2007) also stress that case study researchers must be aware of bias, to attempt not to affect the subjects' production of data, and also to check for credible and reliable evidence of the phenomenon under study. For these reasons, I sought to apply 'methodological triangulation' (Cohen et al., 2007: 142) in order to aspire to a higher degree of objectivity. Research data were thus collected in various forms: through students' written classwork and homework, my own observation journal, pre-project and follow-up questionnaires, reflective work produced by students on their production work, and the media text itself.

'Inductive thematic analysis' (Braun and Clarke, 2006: 12) was chosen as a means of data analysis. I started with the 'in vivo codes' (Rivas, 2012: 372) of my data that I later categorized, formulating themes connected with participants' cultural taste and identity. Furthermore, I analysed the emerging themes on a 'latent level' (Braun and Clarke, 2006: 13), seeking to move beyond the explicit level of the meaning of themes, and aiming rather to examine their underlying concepts. I drew on principles from social semiotics (Hodge and Kress, 1988) in attributing meaning 
to my data, whereby it is the social context where data is produced that attributes to it its meaning. In this respect, students' choices for their documentary-making are seen here within a broader context beyond the classroom, as part of a wider framing within the various social, political and economic forces defining their lives and decisions. Recalling the recent dialogue on the role of value in film education in the Film Education Journal (Bernstein and Burn, 2019), my approach in this respect subscribes to Burn's argument that it is theoretical frameworks that lead students into deeper understandings of moving image texts, and that cultural value depends on people's social class and education (Bourdieu, 1984). Consequently, I applied textual (McKee, 2003) and multimodal analysis (Kress and Van Leeuwen, 2001, 2006). In terms of the former, I studied the collected data in order to explore how the language used reflected the broader social realities of the students' lives, while the latter allowed me to draw similar conclusions after examining and interpreting the multimodal material, in terms of the oral and written speech, image and sound included in the students' documentary work.

Situated within this analysis, the students' documentary-making choices can be seen as a combination of their pre-existing knowledge of documentaries, the application of the theory they were taught by me in class, and - in certain moments the application of techniques drawn from popular culture. This gave rise to an interesting clash (but also coexistence) of popular and classical culture, which I go on to explore.

In the pre-project questionnaire exploring students' previous documentaryviewing and video-making experiences, most students appeared to be only occasional viewers of documentary. The documentary topics for which they expressed a preference varied from wildlife and natural phenomena to historical events, and social and cultural issues. Students frequently held opinions about the content of the documentaries that they watched, and they wanted to have the freedom to choose what they watched. In this respect, the students can be seen, to some extent, as mature, relatively powerful media consumers with some knowledge of the documentary genre and certain expectations from it (Buckingham, 2003). When engaging with the film education project in question, they arrived with a pre-existing cultural burden - what Bourdieu (1984: 13) describes as 'cultural capital' - inherited from their social environment (in terms of their family, peers, exposure to various media, urban environment and previous formal education). While their knowledge so far was mainly unofficial and acquired outside school, all these influences can be seen to have formed their taste in documentaries.

When analysing the narratives of media texts, students tended to exemplify theory through references to Hollywood films such as Troy (2004). This demonstrated their engagement with global popular films, applying academic material taught in class to pre-acquired informal knowledge (Buckingham, 2003; Burn and Durran, 2007), and the use of their experiences of popular culture in class contributed to the development of broader conceptual understandings (Parry, 2014). As Marsh (2000: 130) argues, 'popular culture can provide a means of locating new understandings within familiar discourse'. Further, one student within the group made an association between narrative techniques adopted in media texts and those of print texts, by referring to taught material from the school's ancient Greek literature module. In both instances, the students' 'cultural capital' (Bourdieu, 1984) emerged (as they mentioned audiovisual or print texts to which they had been exposed, either through the media or in their official education) and was subsequently mobilized (Cannon et al., 2018) within the project's framework to contribute to their new creation. 


\section{Scriptwriting and production}

During the scriptwriting process, Student $\mathrm{H}$ wrote that, in modern Tampouria, 'Concerts, parkour and dance competitions are organized among teenagers, and also cultural events and various other happenings.' These aspects of twenty-first-century youth culture, important within the students' cultural lives, can be seen to play a part in their 'lifestyle' (Bennett, 2001: 1), belonging to their current 'lived' cultural context (Williams, 1961: 66). Further, these common interests serve to unite young people, and to create 'distance between themselves and more mundane everyday life institutions such as the family [and] school' (Bennett, 2001: 5). During the making of the documentary, Student $\mathrm{H}$ also suggested shooting her friends doing parkour, a popular activity among young people in Tampouria. The student's choice in this respect could also be related to the expression of her youth identity, as distinguished from the world of adults - a choice to focus on young people's activities and cultural forms, given that the film was made by local young people. Further, as such activities flourished in the student's surrounding working-class urban environment, her expressed preference in this respect suggests a connection between culture and social class (Hodge and Kress, 1988). While working within the semiotic mode of images, Student $H$ thus made a connection with her familiar popular culture experiences, showing how her conceptual understanding of film language had developed (Marsh, 2000; Parry, 2014).

Later on, during the production of the film, the group were shooting images of graffiti in a park near to an open-air theatre, where two girls who attended hiphop dance lessons (and sometimes danced in the schoolyard) spontaneously started breakdancing. This dance, emerging from the girls' lifestyle and cultural tastes, ultimately became a scene in the documentary, illustrating (through an appropriate use of semiotic tools) an aspect of youth popular culture through combining a shot of the girls breakdancing with the song 'Radek vs Amélie [BreackDance evolution]' (Marionette and Tiersen, 2007) and a voice-over referring to the youths' activities. The editing of this scene can be seen as indicative of how the exploitation of students' cultural experiences during production contributed to their conceptual understanding and application of film language (Parry, 2014).

Additionally, the adaptation of global popular culture to the local context in which they lived recalls Askegaard and Kjeldgaard's (2006: 232) discussion of 'glocalization'. While teenagers - such as the girls breakdancing in the film - participated in dance events organized in urban settings not dissimilar to those elsewhere in the world, the music genre to which they listened, hip hop, was frequently written and sung in Greek by Greek artists. Indeed, Greek hip hop has its own varied form, low bap: 'a sub-genre of the Greek hip hop music scene that emerged in the mid-1990s. ... characterized by slower tempo and rapping than usual, clean, loud beats and deep lyrics, often with political content' (Last.fm, 2015). In this respect, a glocal art form can be seen to express young people's worries and concerns in their mother tongue, and again formed part of their lifestyle, since individuals choose lifestyle through 'the dialectical interplay of the local and the global' (Giddens, 1991: 5). Young people's lifestyle can thus be seen as an aspect of their identity, a feature of contemporary glocal life, especially for younger generations.

The aspects of glocalization apparent in the students' cultural taste was underpinned by their choice of music for their documentary soundtrack. In the beginning of the film, in the sections referring to the Greek Asia Minor refugees, and at the end of the documentary, the students used the opening section of a Greek low bap

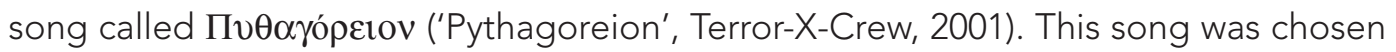


at Student H's suggestion, because, as she stated, 'It talks about the Greek Asia Minor refugees, and Tampouria hosted these refugees when they arrived. Also, its introductory instrumental part doesn't cover the documentary narration, while it is typical music of the refugees' motherland.' In this way, students expressed their preference for a global music genre with strong local influences, a glocal cultural product indicative of their cultural tastes. The students' choice in this respect also showed that they had achieved a certain level of understanding regarding the use of the semiotic mode of music, thanks to its connections with their popular culture music experiences (Marsh, 2000; Parry, 2014). The choice of a low bap song was also indicative, to some extent, of the social class background of many of the students (Hodge and Kress, 1988). Low bap is particularly popular in working-class suburbs of Greek cities and has not been fully adopted by the wider youth community, thus carrying implicit connotations of suburban neighbourhoods.

The other two music tracks chosen for the documentary were drawn from popular culture. 'La valse d'Amélie' (Tiersen, 2001) was chosen as the main theme of their documentary because, as Student E explained, 'It is instrumental and doesn't prevent the narration from being well heard. It is also a relaxing tune, appropriate for historical narration, and, most importantly, it has a breakdance remix ['Radek vs Amélie [BreackDance evolution]' (Marionette and Tiersen, 2007)], appropriate for referring to modern Tampouria.' This use of music would seem to support Hodge and Kress's (1988: 238) claim that children do not come naively to a text, but rather bring their social and cultural influences with them. Further, I would argue that during the process of music selection, students were defamiliarized from this popular music track, re-examined it under the scope of official education and gave a new meaning to it, considering it to be rather 'classical' (Connolly, 2013). Afterwards, they turned to the breakdance version of this track when referring to modern Tampouria, as this was more appropriate for the sense of a contemporary present that they wanted to represent from their own perspective, employing rhythms closely related to their cultural taste. All three pieces of music selected were thus drawn from the place of music in the students' wider social realities, and their use in the documentary could be seen to support Parry's (2014) argument that the legitimization of popular culture in class settings contributes to students' conceptual understanding of film language.

Additionally, the use of various graffiti shots as a means of representing modern Tampouria can be seen as indicative of the students' cultural taste. Graffiti is also a form of glocal culture, combining the global art form of graffiti with the local themes and concerns of Tampouria. The students' insistence upon shooting specific aspects of graffiti shows not only their perception of graffiti as an art form - the product of various influences, including peer culture, international media and the urban landscape - but also their ability to judge different aspects of graffiti and distinguish what was worthy of being filmed. During the film's editing process, the girl who shot and edited the shots of graffiti suggested using an image of a rose (Figure 1) to accompany the statement in the narration that 'today the area is the "home" of many young people'. As she said, this 'rose is a flower in blossom and it can stand for the youth'. Here, the student can be seen to be making a connection between her own cultural tastes and her identity as a young person, as symbolically embodied by the rose. Simultaneously, such a choice arguably demonstrates a certain 'reflexivity of the self' (Giddens, 1991: 7). During the editing of the graffiti shots, students placed the colourful graffiti shots with an emphasis on the red rose in counterpoint to the 'Radek vs Amélie [BreackDance evolution]' music track, and narration about the present of Tampouria, in order to represent contemporary local experiences through a set of complementary modes. 


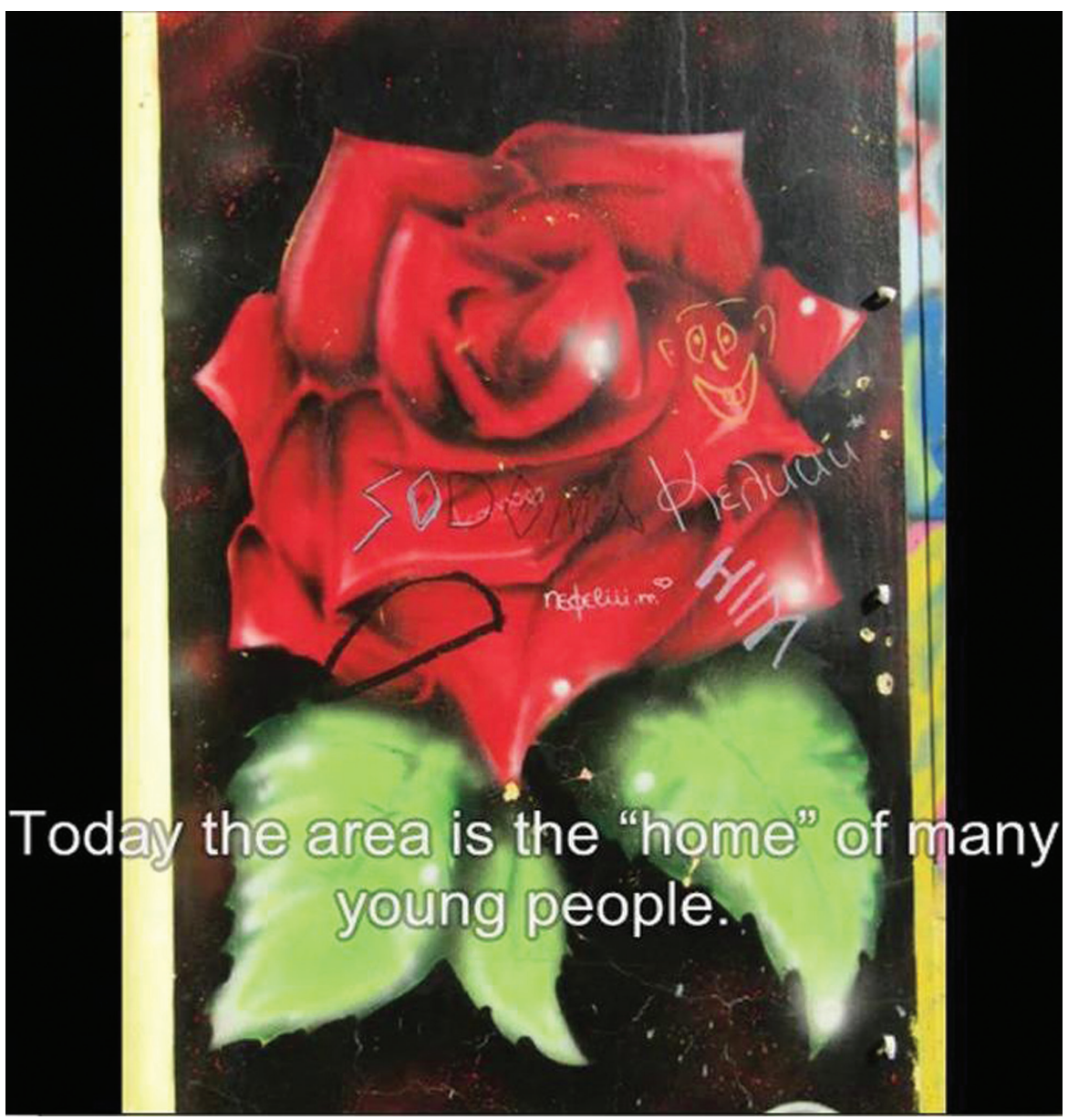

Figure 1: Screengrab from the documentary showing the rose graffiti (source: author)

An important element of the historical heritage that the students drew upon during the making of the documentary was Karagkiozis shadow theatre, an aspect of Greek traditional folk culture that is mainly directed towards children. Karagkiozis shadow theatre dates back to the occupation of Greece by the Ottoman Turks, and embodies satirical performances through which the oppressed Greeks covertly made fun of their occupiers. As most Greek children attend Karagkiozis performances, the students enjoyed the references made to them in the 'talking head' interviews featured in the film, as it seemed to bring back pleasant memories from childhood. On the contrary, however, two Albanian students mentioned that they did not like Karagkiozis performances. In this respect, the project served - to an extent - to defamiliarize students from an aspect of their host country's folk culture, helping them revisit it and attribute a new meaning to it through the learning process (Connolly, 2013), thus connecting folk culture with the educational process (Boughton and Mason, 1999). The Albanian students were impressed by the explanation of Karagkiozis shadow theatre and its history that they received, and one exclaimed: 'Wow, miss, I didn't know all that!' In this respect, students' cultural taste can, of course, be seen to be dependent on cultural experiences related to their national identities.

In terms of the conclusion of the documentary, the choice of a graffiti image as the visual material of the scene and the Asia Minor-style tune from the introduction of the low

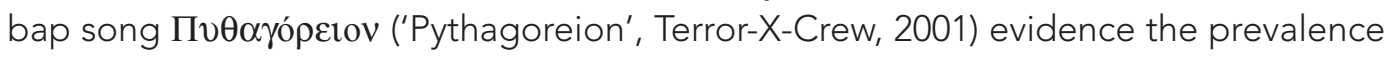
of contemporary popular youth culture in the teenagers' preferences. Additionally, 
the use of Asian Minor-style music related to the Asia Minor refugees articulates the students' sense of the history of the neighbourhood, while also, perhaps, implying an understanding that Tampouria has always tended to welcome foreigners in need. Half of the group's participants came from immigrant families, and the students explicitly mentioned the 'different nationalities' of Tampouria inhabitants in their narration (see below). The lyrics used for the accompanying voice-over were drawn from a Greek song (by local singer Stelios Kazantzidis) popular among the working-class generation of their parents. After several decades of popularity, the song that the students used might be considered to be a classic in Piraeus; it refers to Piraeus port, and mentions the neighbourhood of Tampouria, and its lyrics were chosen by the class after a group discussion. Stelios Kazantzidis, who wrote the song, was a popular singer of the 1960s who largely performed songs about Greek emigrants. All the students liked the idea of using lyrics by Kazantzidis because he had been a resident of Tampouria for some time. In this respect, the reference to a singer connected with the area that was 'popular' in the past, and 'classical' in the present, seemed to the students to be a fitting way in which to bring the different generations together in an articulation of local identity. (In this respect, one can perhaps see this use of Kazantzidis's lyrics as an appeal to Tampouria's 'imagined community', whose members feel a kind of bond among themselves despite not knowing each other (Anderson, 1983).) The students felt the need to unite aspects of the past with the present in order to summarize what they felt was Tampouria's double identity, in terms of what it meant simultaneously to older generations and to them. Despite the emphasis on Greekness articulated through the choice of these lyrics, the fact that they referred to Greek emigrants might also be seen to touch upon the contemporary issues of immigration in Greece affecting a number of the student participants, as touched on below.

The graffiti used in this concluding scene - the name of 'Tampouria' painted in Greek - was perhaps the most striking use of graffiti in the film, and was made expressly for inclusion in the documentary by the brother of one of the participants (Figure 2). Here, the students chose to end their film with a typical representation of their popular cultural taste, articulating their local identity as Tampouria inhabitants.

An interesting debate arose within the group regarding the representation of the present and the past in the final scene. While one student wanted the documentary to finish with the words 'our area is our home and our home is our area', and to omit the singer's lyrics, another student felt strongly that combining Kazantzidis's lyrics with the Tampouria graffiti was a combination of the past and the present that would bring the audience back to the significance of the film's title. As she said: 'It is like remembering the past and living the present. Otherwise, if we conclude with just a reference to the present, it will be like ignoring the past.' While the first student felt it was important to stress in the documentary that their area was their home, defining their field of action and placing emphasis upon contemporary culture associated with their local and social identity, the second student (and, with her, the rest of the group, who agreed with her) wished to prioritize a more rounded understanding of culture and identity. They felt the need for the film's conclusion to express Tampouria's historical importance, while also acknowledging its present. In this respect, they sought to express the cultural taste and preferences of both current and previous generations, attempting to reconcile the two on the basis of a shared celebration of Tampouria as a key influence upon their lifestyle and cultural preferences, and their local identity through time. The local history presented by the students in the documentary can be seen to be the product of various factors. Much of 'the past', as a temporality not directly experienced by the students, consisted of 


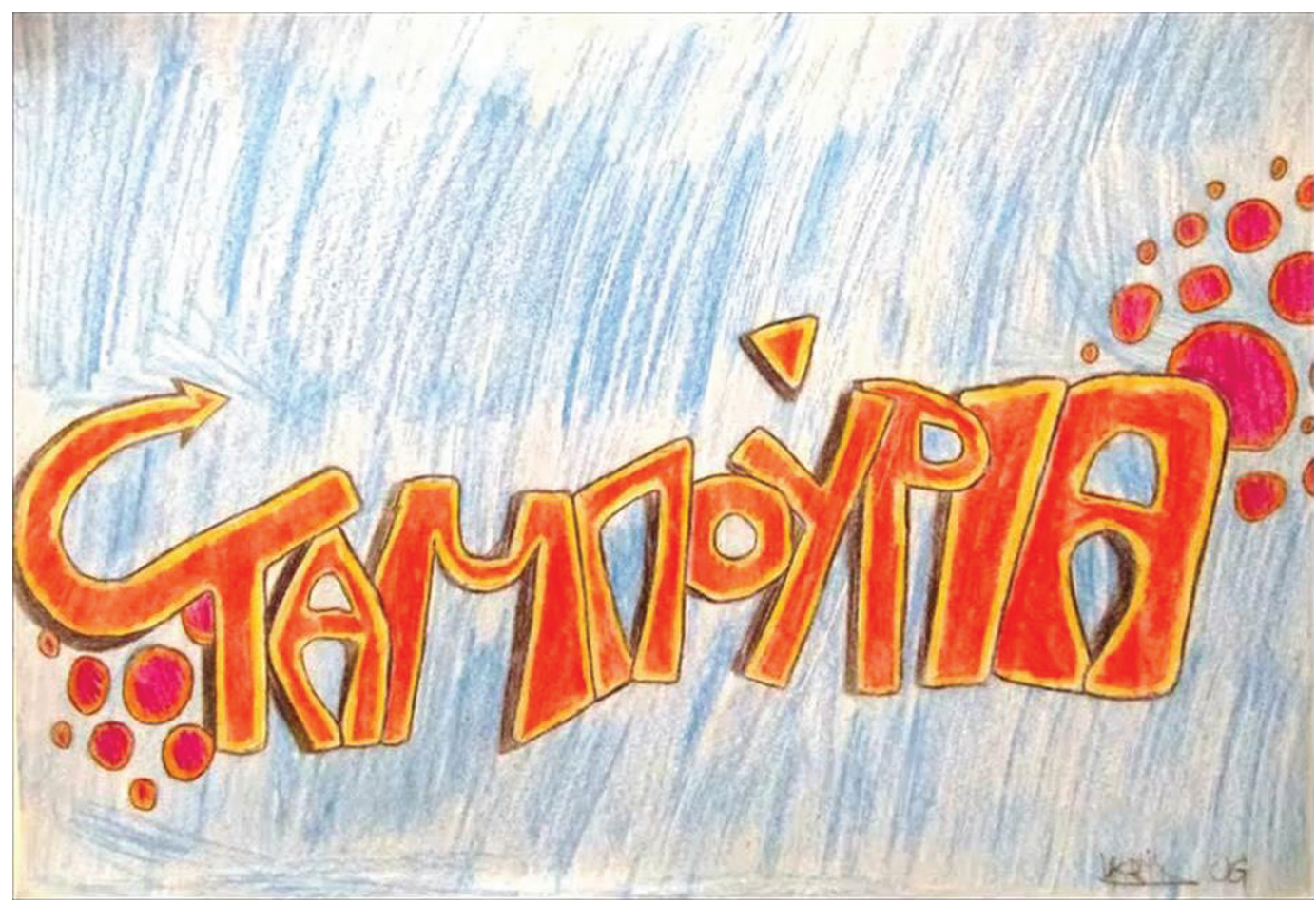

Figure 2: Screengrab from the documentary showing the last graffiti shot (source: author)

a series of images in their minds formed by the reading of history books, exposure to archive material in school settings, documentaries, family narrations (with and without the use of visual material such as photographs) and a broader cultural memory of past experiences inherited from the communities of which the students were a part.

When the group initially discussed the visual material that would accompany their narration, and how the nineteenth-century history of the area would be depicted in the film more generally, Student $C$ suggested, 'We need to take some shots of St George Church and of Tampouria square, where Karaiskakis, the Greek Revolution hero, took action, and also we need to find paintings of him.' Georgios Karaiskakis's role in the Greek Revolution against the Ottoman Turks seemed of crucial importance to the Greek students, serving to highlight both the historicity of the area, and its role in the independence and history of modern Greece. These aspects of Tampouria's history touched upon the students' sense of national identity, and a sense of living in a neighbourhood with a heroic past. Such stories seemed to articulate a sense of honour for them, and the sense that their ancestors were possibly connected to Karaiskakis or involved in the battles of liberation. As such, these events served as an articulation of the students' historical heritage, highlighting the social and cultural history they carried and wished to project in their work (Hodge and Kress, 1988: 238). For the students from immigrant families, this historical reference provided a source of peer learning about the past of the area, adding to the information to which they had access from their official education, non-educational history books, media and online material. Moreover, both Greek and immigrant students were exposed to references to these events and their protagonists in the public celebrations organized on national public holidays. In these terms, such aspects of history can be seen to play an important part in the culture and the 'collective memory' (Marcel and Mucchielli, 2008) of the community in which they lived. Despite this, the immigrant students seemed to experience certain degrees of 
emotional distance from such aspects of history, as - coming from a different country and belonging originally to a different cultural community - this 'collective memory' was not initially part of their own repository of 'cultural memory' (Straub, 2008). In this respect, they then had to 'defamiliarise' (Connolly, 2013) themselves from this part of the history and reconsider it, attributing new degrees of meaning and importance to it in relation to the location they inhabited.

Students' suggestions regarding how the present should be depicted in the film seemed to be largely related to locations in Tampouria that they themselves frequented, art forms they liked ('walls with graffiti') and activities they enjoyed ('places with young people skateboarding and doing parkour') - much of which reflected aspects of glocal youth identity. Despite this emphasis on aspects of contemporary youth identity, students seemed to be aware of how certain things used to be part of the life of their communities, and how things are different now. Since the students' images of the past were formed by their social context, their various influences added to their cultural burden and conception of the world (Hodge and Kress, 1988). Interestingly, students seemed to prefer either old sepia or black-and-white photographs, or using similar effects on new photographs in order to depict the past. Since the historical material to which they had been exposed so far were in these colours, they wished to make use of this aesthetic as proof of the validity and credibility of the information they included in the film. It could thus be said that it was the conception of the past possessed by both the local and national communities in which they lived that contributed to the formation of the students' 'collective memory', guiding their representation of the past through the use of the semiotic mode of images.

\section{Screening and evaluation}

As the final documentary was to be screened in the end-of-school-year celebration, it had to address both the school's teenage students and their parents and teachers, as well as representatives of the Educational Office of Piraeus. Therefore, the film's intended 'interpretive community' (Buckingham, 2003: 38) can be seen to be relatively wide, including people of various ages, most of whom knew the area. The response of the audience stressed the importance of the locality both for the students who made the film and for its viewers, as the film was highly appreciated by both groups, as I will now explore.

During the documentary screening, the audience, most of whom lived in Tampouria, received the film with enthusiasm. While those who had lived in the neighbourhood all of their lives seemed to find the film touching, newer arrivals to the neighbourhood seemed to focus more upon the presentation of local history. The students' parents, as well as schoolteachers and other students, seemed excited about the students' work. According to the accounts of the students themselves, their siblings liked the film, and one of them described it as 'touching', while their grandparents were more emotionally involved, and two of them were reportedly moved to tears.

The students' particular interest in local history became apparent in the project's written evaluation. Students from Albanian families expressed satisfaction for having worked on the project, particularly as they now felt more informed about the history of the area they inhabited, having had the chance to discover it themselves and represent it in their own way. Student $E$ wrote that 'I liked dealing with this project because I learnt a lot of things about the area of Tampouria that I didn't know before and I showed what it means to me.' Testimonies of this sort suggest that the students were able to mobilize existing cultural capital (Cannon et al., 2018), then 'defamiliarised' 
(Connolly, 2013) themselves from what they knew about local history and reconstructed their knowledge, approaching it through the lens of this video-making project.

The group's Greek students also highlighted the satisfaction they had taken from the project, and in particular from the chance to learn about, work on and present to an audience a topic which they liked and in which they were interested, while expressing aspects of their own cultural taste through creative practice. This would seem to support Marsh et al.'s (2005) claim that the integration of popular culture in formal education increases the engagement of children in the learning process. Student A described how 'I was impressed by what I learnt through the project about the history of my area', while Student C stated: 'I enjoyed working on this documentary project. The idea was wonderful because we dealt with something that made sense.' Moreover, students expressed a strong sense of belonging to Tampouria, with most using the possessive 'my area' in their statements. These Greek students were all born and raised in the neighbourhood, as were either both or one of their parents, a fact underlining the importance of the social history articulated in the film (Hodge and Kress, 1988), given their strong bonds with Tampouria's sense of place and awareness of its historical importance.

The film can be seen, complexly, to articulate certain aspects of the students' national identity. The concept of homeland arguably has a particular meaning in Greek popular consciousness, denoting both 'a real or imagined homeland' (Cohen, 2007: 4), a country one belongs to no matter where one lives. Blickle (2002) states that 'Heimat' (homeland in German) is a body part you can neither get rid of, nor want to get rid of. Similarly, Blioumi (2007: 520) argues that "'Greekness" ... expresses the concept of Hellenism as a cultural set of fixed points of reference throughout the centuries'. I argue that these points are taken for granted by a broad swathe of the Greek community, comprising certain degrees of national, cultural, religious and linguistic uniformity (Christopoulos, 2002, cited in Blioumi, 2007: 520). Despite such broadly shared notions, this concept of homeland ( $\pi \alpha \tau \rho i \delta \alpha\left(/ p \Lambda^{\prime}\right.$ trið$\left.\left.\Lambda /\right)\right)$ has become a complex concept in Greece due to recent tensions around immigration and the phenomenon of transculturalism. Since the arrival of large numbers of immigrants has been a quite recent phenomenon in Greek society - starting in the 1990s and still in progress - questions of national identity and sense of belonging for second-generation immigrants are still being negotiated. According to Blickle (2002: 4), 'Another aspect of Heimat will ... remain insistently part of geography, ... in the largest sense, of the country where one has grown up or at least lived for an extended period.' Thus, while children from immigrant families are born and raised in Greece (the country many feel to be their homeland), there are other aspects of nationality and culture within their families with their roots outside Greece. Half of the students in the group belonged to this category, thus defining their national identity through an ongoing process of adaptation and blending of their family national identity with that of their host country (Blioumi, 2007).

The way students began their narration of the section of the film pertaining to present times was also indicative of how they perceived their area: 'Tampouria of today is a modern multicultural neighbourhood of Piraeus. ... Now Tampouria has been transformed from a historic Greek place into a modern environment, where people of different nationalities coexist harmoniously despite their diverse cultures and lifestyles.' First, students focused on the 'multicultural' aspect of their area, where 'people of different nationalities coexist harmoniously', as seemed to reflect their everyday experience, both inside and outside school. Students felt the need to stress that, while there was unity among them, this was not a national or cultural uniformity, as underlined by the emphasis upon 'diverse cultures and lifestyles'. Students thus 
seemed both aware and sensitive to their national and cultural differences, a social reality reflected in their work (Hodge and Kress, 1988). They wanted to talk about their area, as they all felt themselves to be members of the same 'imagined community' (Anderson, 1983: 48) of Tampouria inhabitants.

\section{Conclusion}

In conclusion, during the documentary film-making project, various aspects of the students' cultural taste and identity came to the surface. The students' cultural taste in this respect can be seen as a complex combination of global and local cultural influences, resulting in the production of glocal (Askegaard and Kjeldgaard, 2006) cultural products. This glocal youth culture, as articulated in their documentary work, derived from their exposure to various influences and the convergence of global and local habits, lifestyles and cultural products. At the same time, the students' ability to connect experiences of popular culture with the documentary-making process facilitated their conceptual understanding of film language (Parry, 2014), as they could develop the newly introduced concepts in an already familiar discourse (Marsh, 2000). On the one hand, students carried strong influences from global popular culture - hip hop music, graffiti, breakdance. On the other hand, interesting issues arose regarding questions of national history and tradition. Although global popular culture was omnipresent in their creative work, the role of more traditional elements was not ignored. Both the Greek and the immigrant students reached common decisions supporting the latter, and found a place for them in their short documentary. Furthermore, at times, students attributed new meanings to already familiar popular culture products through processes of defamiliarization (Connolly, 2013).

Representation of the past and references to local history seemed to be of crucial importance to the students. The means that they used to represent Greek refugees' arrival from Asia Minor, and their insistence upon referring to Karagkiozis folk shadow theatre, emphasized the students' conception of the historical importance of their locality and folk tradition respectively. Elements of their sense of nationality were also revealed through the representation of their locality and through the priority they attributed to aspects of cultural tradition.

The family also seemed to play an important role in the formation of the students' cultural taste, with their conception and representation of the past seemingly informed by family narrations and memories, 'integrat[ing] home experiences with schooled literacy' (Marsh, 2000: 130). Parents' social class was another way in which the family could be seen to define student experiences, preferences and mentalities (Hodge and Kress, 1988). In the specific case of their documentary film work, a desire to subvert established orders can arguably be seen to be expressed in particular through the art forms of graffiti and low bap music.

Ultimately, the project can be seen to have given students the opportunity to express themselves, while shedding light on various aspects of their identity: their local identity as related to their Greekness (Blioumi, 2007) or foreignness; their collective memory; and their glocal youth identity, formed by a combination of global and local youth influences. The idea of homeland, for both Greek and immigrant students, and how it related to the specific area where they lived, along with the collective memory (Marcel and Mucchielli, 2008) of the wider communities and the imagined communities (Anderson, 1983) of which they were a part, seemed to form a means of conceiving the past and present of their locality. This representation of past and present was also manifest in an interplay between classical and popular culture; while the students 
focused mainly on the latter in depicting aspects of their youth identity, both played an important role when it came to depicting their local identity and some of the local characteristics of Tampouria.

\section{Notes on the contributor}

Eirini Arnaouti is an English teacher in Evangeliki Model High School of Smyrna, Athens, Greece. She delivers teacher-training seminars in Greece, and has presented and published her work in a series of international forums. Her key research interests are in media literacy and interdisciplinary education.

\section{Filmography}

Troy (US 2004, Wolfgang Petersen)

\section{References}

Anderson, B. (1983) Imagined Communities: Reflections on the origin and spread of nationalism. London: Verso.

Askegaard, S. and Kjeldgaard, D. (2006) 'The glocalization of youth culture: The global youth segment as structures of common difference'. Journal of Consumer Research, 33 (2), 231-47. https://doi.org/10.1086/506304.

Bailey, K.D. (1994) Methods of Social Research. 4th ed. New York: The Free Press.

Bennett, A. (2001) Cultures of Popular Music. Philadelphia, PA: Open University Press.

Benyahia, S.C. (2007) Teaching Film and TV Documentary. London: British Film Institute.

Bernstein, A. and Burn, A. (2019) 'Perspectives: A dialogue upon the question of value in film education'. Film Education Journal, 2 (1), 71-83. https://doi.org/10.18546/FEJ.02.1.06.

Blickle, P. (2002) Heimat: A critical theory of the German idea of homeland. New York: Camden House.

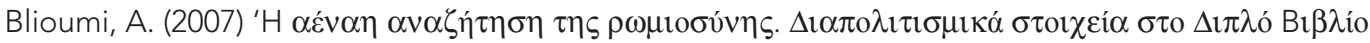

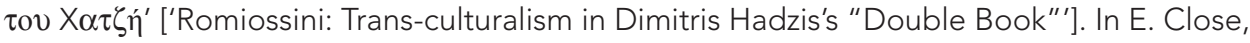
M. Tsianikas and G. Couvalis (eds), Greek Research in Australia: Proceedings of the Sixth Biennial International Conference of Greek Studies, Flinders University, June 2005. Adelaide: Flinders University Department of Languages - Modern Greek, 517-26. Accessed 15 March 2021. http://hdl.handle.net/2328/3292.

Bordwell, D. and Thompson, K. (2010) Film Art: An introduction. 9th ed. New York: McGraw-Hill.

Boughton, D. and Mason, R. (eds) (1999) Beyond Multicultural Art Education: International perspectives. Munster: Maxmann.

Bourdieu, P. (1984) Distinction: A social critique of the judgement of taste. Trans. R. Nice. Cambridge, MA: Harvard University Press.

Braun, V. and Clarke, V. (2006) 'Using thematic analysis in psychology'. Qualitative Research in Psychology, 3 (2), 77-101. https://doi.org/10.1191/1478088706qp063oa.

Buckingham, D. (2003) Media Education: Literacy, learning and contemporary culture. Cambridge: Polity Press.

Burn, A. and Durran, J. (2007) Media Literacy in Schools: Practice, production and progression. London: Paul Chapman.

Cannon, M., Potter, J. and Burn, A. (2018) 'Dynamic, playful and productive literacies'. Changing English: Studies in culture and education, 25 (2), 183-99. https://doi.org/10.1080/135868 4X.2018.1452146.

Cohen, R. (2007) 'Solid, ductile and liquid: Changing notions of homeland and home in diaspora studies'. Paper presented at the Dispersione, "globalizzazione" e construzione dell' alterità: diaspore e migrazioni nel bacino del Mediterraneo ed oltre (XIX-XX secc.) Conference, Marsala, Italy, September.

Cohen, L., Manion, L. and Morrison, K. (2007) Research Methods in Education. 6th ed. London: Routledge.

Connolly, S. (2013) 'Learning Progression in Secondary Students' Digital Video Production'. PhD thesis, UCL Institute of Education. 
Dyson, A.H. (2002) Brothers and Sisters Learn to Write: Popular literacies in childhood and school cultures. New York: Teachers College Press.

Giddens, A. (1991) Modernity and Self-Identity: Self and society in the late modern age. Stanford, CA: Stanford University Press.

Gilje, O. (2010) 'Multimodal redesign in filmmaking practices: An inquiry of young filmmakers' deployment of semiotic tools in their filmmaking practice'. Written Communication, 27 (4), 494-522. https://doi.org/10.1177/0741088310377874.

Hodge, R. and Kress, G. (1988) Social Semiotics. Cambridge: Polity Press.

Kress, G. and Van Leeuwen, T. (2001) Multimodal Discourse: The modes and media of contemporary communication. London: Hodder Education.

Kress, G. and Van Leeuwen, T. (2006) Reading Images: The grammar of visual design. 2nd ed. London: Routledge.

Last.fm (2015) 'Low bap music'. Accessed 21 April 2021. www.last.fm/tag/low+bap/wiki.

Marcel, J.-C. and Mucchielli, L. (2008) 'Maurice Halbwachs's mémoire collective'. In A. Erll and A. Nünning (eds), A Companion to Cultural Memory Studies: An international and interdisciplinary handbook. Berlin: De Gruyter, 141-9.

Marionette and Tiersen, Y. (2007) 'Radek vs Amélie [BreackDance evolution]'.

Marsh, J. (2000) 'Teletubby tales: Popular culture in the early years language and literacy curriculum'. Contemporary Issues in Early Childhood, 1 (2), 119-33. https://doi.org/10.2304/ ciec.2000.1.2.2.

Marsh, J., Brooks, G., Hughes, J., Ritchie, L., Roberts, S. and Wright, K. (2005) Digital Beginnings: Young children's use of popular culture, media and new technologies. Sheffield: Literacy Research Centre, University of Sheffield.

McKee, A. (2003) Textual Analysis: A beginner's guide. London: Sage.

Ministry of Education, Lifelong Learning and Religious Affairs (2010) ' $\Sigma$ XE $\Delta I A \Sigma M O \Sigma K A I$

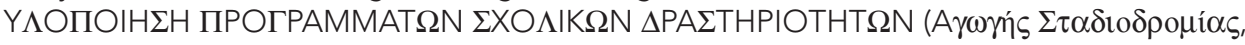

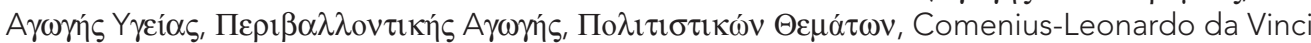
Kol eTwinning) ГIA TO $\Sigma$ XO IIKO ETO $\Sigma$ 2010-11' [Design and Realisation of School Projects (Professional guidance, health education, environmental education, cultural themes, ComeniusLeonardo da Vinci and e- twinning) for the school year 2010-11]. Athens: Ministry of Education, Lifelong Learning and Religious Affairs.

Nichols, B. (2010) Introduction to Documentary. 2nd ed. Bloomington: Indiana University Press.

Parola, A. and Ranieri, M. (2010) Media Education in Action: A research study in six European countries. Florence: Firenze University Press.

Parry, B. (2014) 'Popular culture, participation and progression in the literacy classroom'. Literacy, 48 (1), 14-22. https://doi.org/10.1111/lit.12027.

Pérez-Rodríguez, A. and Delgado-Ponce, Á. (2012) 'From digital and audiovisual competence to media competence: Dimensions and indicators'. Comunicar, 39, 25-34. https://doi.org/10.3916/ C39-2012-02-02.

Rivas, C. (2012) 'Coding and analysing qualitative data'. In C. Seale (ed.), Researching Society and Culture. London: Sage, 366-92.

Straub, J. (2008) 'Psychology, narrative, and cultural memory: Past and present'. In A. Erll and A. Nünning (eds), A Companion to Cultural Memory Studies: An international and interdisciplinary handbook. Berlin: De Gruyter, 215-28.

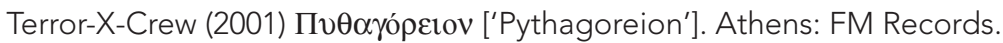

Tiersen, Y. (2001) 'La valse d'Amélie'. Paris: Virgin Records US.

Williams, R. (1961) The Long Revolution. London: Chatto \& Windus. 